\title{
The reference to constitutional traditions in populist constitutionalism - The case of Hungary
}

\author{
FRUZSINA GÁRDOS-OROSZ ${ }^{1,2^{*}}$
}

${ }^{1}$ Centre for Social Sciences Institute for Legal Studies, Budapest, Hungary

${ }^{2}$ ELTE Law School, Budapest, Hungary

\section{ORIGINAL RESEARCH PAPER}

Received: August 11, 2020 • Revised manuscript received: February 07, 2021 • Accepted: March 04, 2021

Published online: June 8, 2021

(C) 2021 The Author(s)

\begin{abstract}
The paper aims to highlight the nature and the relevance of the reference to constitutional traditions in the building of populist constitutionalism, with special regard to the Hungarian case. In Hungary the goals and effects of this reference - especially the references to the achievements of the historical constitution - must be discussed at the level of the constitutional text and with regard to the formation of the new constitutional jurisprudence and, furthermore, to the creation of the constitutional identity. Outstanding political theories have been built about the elements of national populism and all include a political emphasis on a nation's pride in its culture, history and traditions. This paper examines the normative legal consequences of this in a state where the populist political forces have consecutively gained a majority in the Parliament which enables them to adopt and amend a constitution and decide on the personal make up of the constitutional court. It examines the role of the reference to constitutional traditions in the transformation of the constitutional system. The illustrative case studies from Hungary show one element of the alternative to mainstream liberal constitutional democracy: a constitutional perception of the sovereign people with a
\end{abstract}

\footnotetext{
*Corresponding author. E-mail: orosz.fruzsina@tk.hu

I am grateful for the suggestions and recommendations of Prof. Zoltán Szente and for the much valued comments of the anonymous reviewers. This research has received funding from the European Union's Horizon 2020 research and innovation programme under grant agreement No. 822590, DEMOS - Democratic Efficacy and the Varieties of Populism in Europe - (any dissemination of results here presented reflects only the authors' view. The Agency is not responsible for any use that may be made of the information it contains) and the 29245 program on Populism in policy and law making, funded by the National Research Development and Innovation Office.
} 
strong common constitutional heritage, this latter to be respected by all state organs and by domestic, European and international law. The paper offers an understanding of this constitutional concept and assembles disclaimers and serious legal concerns that must be taken into account, at least in Hungary, but probably in many other national populist regimes as well.

\section{KEYWORDS}

populist constitutionalism, Hungarian constitutionalism, the Fundamental Law of Hungary, the historical constitution, the achievements of the historical constitution, constitutional identity

\section{INTRODUCTION ${ }^{1}$}

How is that nativist, authoritarian populisms have become so powerful worldwide? asked Bojan Bugaric, one of the leading scholars of populism, in the German Law Journal in 2019. To be attractive to citizens populist policy making is focused on creating a constitutional environment for its operation to prove the maintenance of the rule of law instead of the prerogative state. The reinterpretation of popular sovereignty, constitution making, and the creation of a constitutional identity are three elements to be measured in populist constitutional change. ${ }^{2}$ In Hungary, the reference to constitutional traditions has played an important role - in structuring the people as the source of the sovereignty, in the analysis of the constitution making itself, and equally in the assessment of the creation of the constitutional identity since 2010 .

This paper attempts to investigate this important element of populist constitutionalism, especially of national populist constitutionalism. In Hungary one of the strengths of the new constitutionalism after the 2010 was that not only the political rhetoric but also the related constitutional law started to base its legitimacy on a reference to national traditions. Hungary could be a litmus paper to examine this phenomenon, because in 2010 the Fidesz-KDNP party coalition won a two thirds majority in Parliament, which is a constitution making and constitution amending majority. ${ }^{3}$ Therefore, for the populist party, i.e. for Fidesz, it was possible to go beyond the rhetoric and start amending the constitution immediately in 2010. By the adoption of the new constitution in 2011, and following this, by the 9 amendments to the Fundamental $\mathrm{Law}^{4}$ (constitution) the Government majority could easily implement in the constitution and in the legal system all the changes that it found necessary for the establishment of the new regime.

Luigi Correas writes, in relation to constitutional identity as collective statehood, that for populist regimes constitutional identity is undoubtedly one of the three most important reconstructions of populist constitutionalism. ${ }^{5}$ Roger Eatwell and Mattheu Goodwin, in their book on national populism as a revolt against liberal democracy, call attention to the role of national

\footnotetext{
${ }^{1}$ Bugaric (2019) 390-91.

${ }^{2}$ Correas (2016).

${ }^{3}$ See, Szente and Gárdos-Orosz (2018).

${ }^{4}$ Drinóczi et al. (2019).

${ }^{5}$ Correas (2016).
} 
traditions in the creation of the constitutional identity of national populism. ${ }^{6}$ When Bojan Bugaric describes the 'false promises of quick fixes', ${ }^{7}$ the creation of a constitutional identity and the promise to lead society back to its strong constitutional traditions appear to be examples of these promises. Mudde and Kaltwasser, in their very brief introduction to populism, write about culture as a component of the notion of the people in some populist regimes. Therefore, the reinterpretation of popular sovereignty as a basic element of populism, and the reorganisation of the components of the notion of the people, is essential. ${ }^{8}$ Jan-Werner Müller also points out that populists reject political representation as the representation of the volonté general according to Rousseau's conception. Populists rather talk about the Volksgeist, where the identity and the common culture is much more important then the actual will of the numerical majority (democracy as a pure majority rule). ${ }^{9}$ Blokker, taking this line of thought even further, argues that 'the people' is not a real entity for the populists, in the sense that the concept of the people does not focus on society, it is rather that the people and popular sovereignty have a transcendent, metaphysical content; the people is a 'collective subject' in its own right, based on the traditions, the common suffering in the past and the history that unites a people. ${ }^{10}$ This is where the constitutional traditions fit in, regardless of whether these elements are real or assumed. The idea that common traditions and culture, specifically legal traditions and legal culture are important for statehood is no doubt a true statement. The question is how this reference is used in a modern legal system with a charter constitution where populists rule. What is the place, the role, the nature and the achievements of this proposal and the concerns surrounding it? The paper aims to discuss this problem by demonstrating it through the Hungarian case.

In the first part of this paper (I), I will describe the elements of constitutional populism in general and pay special attention to national populism, as it appears in the academic literature (1.1). After this, I explain the Hungarian case and review the literature proving that the constitutional change that started in 2010 - which produced the Fundamental Law and has so far seen nine amendments to it - is a populist political change with constitutional (and other legal) consequences (1.2). In the second section (II.), I will describe the references in the Fundamental Law to constitutional culture and history, with special regard to the role of the achievements of the historical constitution and the related case law (2.1), before finally turning to the Seventh amendment concerning the introduction of the constitutional identity and also to the description of the related case law of the Hungarian Constitutional Court (2.2). Throughout the second part of the paper I will continuously reflect on the literature that examines the original, historical content of the special notions used in the language of the new constitution, the 2011 Fundamental Law.

\footnotetext{
${ }^{6}$ Eatwell and Goodwin (2018) 7-34.

${ }^{7}$ Bugaric (2019) 392.

${ }^{8}$ Bugaric (2019) 390-95.

${ }^{9}$ Müller (2013) 53.

${ }^{10}$ Blokker (2019), 542.
} 


\section{CONSTITUTIONAL POPULISM}

Blokker and Anselmi, acknowledged scholars of populism, when giving a definition of constitutional populism write that constitutional populism emerges when populists have state authority, obtain power and get into a position in which they are able to influence the content of the constitution. In this case they can influence constitutionalism in a given country. ${ }^{11}$ In Latin America, for example, there are the cases of Chávez's Venezuela and Morales' Bolivia, while in Europe, the constitutional reform carried out by the populist leader in Hungary is particularly emblematic. If we accept the term constitutional populism in spite of the fact that the expression might seem an oxymoron, we can further accept that the basic populist scheme is the 'the sovereign people-as-one. ${ }^{12}$

Paul Blokker identified four analytical aspects of constitutional populism: popular will, majoritarianism, legal resentment and constitutional instrumentalism. ${ }^{13}$ By the term 'popular will', Blokker meant an idealized idea of the people, which is used to build a constitutional architecture alternative to the liberal one. ${ }^{14}$ In this framework, the constitution becomes the main instrument that strengthens the absolute control of political power based on the construction of the idealised people as a united nation with a common constitutional heritage. ${ }^{15}$

\subsection{Populist constitutionalism, the people, the nation and its history}

Even though the use of 'constitutional populism' is relatively widespread in legal research, the phrase has no universally accepted definition. In fact, the meaning depends largely on the context. It has been used in descriptions of the Chinese legal system (or at least a tendency within that system) to prefer the interest of the people over the professional elites. ${ }^{16}$ There is only one known attempt at the theorisation of legal pragmatism, coming from within legal pragmatist quarters; in it the attitude of American law is understood, which prefers the general good of the public and the extension of equal rights over partial interests. ${ }^{17}$ The context given by Blatt and other American scholars for populism is unrelated to the legal reflection of political populism in Europe. ${ }^{18}$ In the USA, it has been a part of the classical debates surrounding judicial review, just like 'popular constitutionalism', since the turn of the millennium. In those debates, 'populism' is not a pejorative word, but one that reflects support for a moderate judicial role, as opposed to judicial activism. The publication that spurred the most widespread academic discussion was Mark Tushnet's Taking the Constitution away from the Courts in $1999 .{ }^{19}$

\footnotetext{
${ }^{11}$ Blokker (2013) and Anselmi (2018) 87.

${ }^{12}$ Anselmi refers to Clause Lefort from 1988. Anselmi (2018) 87.

${ }^{13}$ Blokker (2018) 8.

${ }^{14}$ Blokker (2018) 14.

${ }^{15}$ Anselmi (2018) 89.

${ }^{16}$ See e.g., Zhang (2012).

${ }^{17}$ Batt (1995).

${ }^{18}$ Graber (2021).

${ }^{19}$ Tushnet (1999).
} 
Legal discussion of populism is scarce and is mainly restricted to the fields of constitutional law or constitutional theory. The relevant literature has not established or differentiated the main theoretical trends in the discussion of the legal effects of political populism. Legal research has mainly focused on the description and classification of the legal effects of populism in general. This point is also understood by those involved in the discussion on constitutional populism.

There have been various conceptualisations of the phenomenon in legal studies, and it remains rather unclear. The terminology used has been largely influenced by the political science that underpins it; i.e. it is connected to the evaluation of the political systems under investigation. Therefore, 'authoritarian constitutionalism' is mentioned, ${ }^{20}$ as well as 'autocratic legalism', 'hybrid constitutionalism' ${ }^{22}$ and 'illiberal constitutionality'. ${ }^{23}$ There are a great number of publications with 'populist constitutionalism' or a similar phrase in the title. ${ }^{24}$

The last few years have seen a significant rise in publications which analyse the legal effects of political populism. So far, however, descriptive and comparative studies have dominated the field, with relatively little by way of independent theoretical work on the European experience (the most important exceptions include works by David Landau, Bojan Bugaric, Paul Blokker and Jan-Werner Müller, Gábor Halmai etc.). ${ }^{25}$ Recently, a number of new studies have been published which are aimed at the protection of liberal democracy, or examine its prospects, or recommend ways to stop its erosion. ${ }^{26}$ A different terminology was proposed in the literature, in addition to populist constitutionalism or illiberal constitutionalism, the so called 'hybrid regime' introduced by Steven Levitsky and Lucan A. Way; ${ }^{27}$ the authors - all capturing one or other aspect of the issue - focus on the democratic change.

Populist constitutional claims emerge within a constitutional democracy. Although scholarship usually contrasts liberal constitutionalism with illiberal constitutionalism, and populist with non-populist constitutionalism etc. as I have explained above, it is a fact that these claims appear in old or new constitutional democracies that operate according to well known rules of constitutionalism. The debate about the elements of populist constitutionalism is therefore difficult to identify, because even in states like Hungary, where the populist Government has had a two thirds constitution making majority since 2010 - the old rule is still present in words and in minds. Populist constitutionalism is not written on a blank piece of paper but written between the lines or over the rows of the written constitutional and other legal texts. It is not always obvious what constitutes a new element that can be qualified as an element of the new populist constitutionalism. As the concept develops within the framework of liberal democracy and transforms it step by step, the analysis needs time before we can describe the entire constitutional change in a specific country, and also on a European and an international level. This

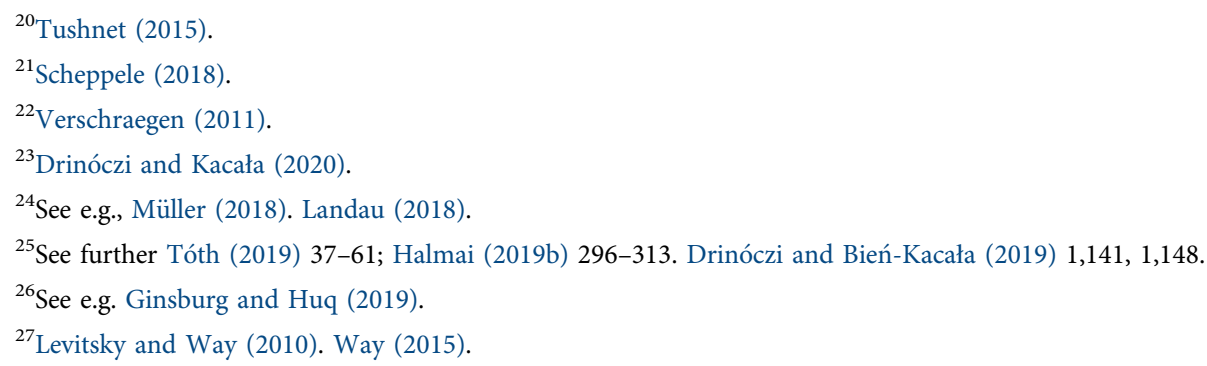


methodological difficulty could be solved by restricting the analysis to one element and assessing whether it is plausible (suitable to the legal system) in a constitutional democracy. By building a structure from the elements that do not appear to be plausible in an established constitutional democracy, we will become able to define populist constitutionalism as something different from classical constitutionalism. Using this methodological approach this paper examines the role of the constitutional traditions in law, and specifically the reference to the so called historical constitution in Hungary as a source of law in the contemporary legal order based on the Fundamental Law of 2011.

In spite of its uncertain content, populism is a good framework for the analysis of the criticism levelled at the constitutional state, because it does not mean anything, ${ }^{28}$ even though it refers to a claim to alter or to change democracy. Populists want to make a difference, no matter in what direction; right or left, ${ }^{29}$ good $^{30}$ or bad. ${ }^{31}$ When building this structure step by step, we will see in the end what kind of populism was created in a certain country in relation to liberal constitutional democracy as the comparatum. There will be similarities and differences in these structures and in the end we can compare them. This methodology is, of course, already applied in legal scholarship and in political sciences and there are some common features of the regimes we qualify as being in a constitutional transformation.

Zoltán Szente, in the introductory chapter of the book Populist Challenges to Constitutional Interpretation in Europe and Beyond, identifies the elements of populist constitutionalism in the negative and in the positive sense, based upon a wide review of the literature in law and in political science. He describes how these elements can be found to different extents in different countries, but in the legal and political science scholarship, these characteristics appear to be basic elements of the concept of populist constitutionalism. The elements are the following: (1) a criticism of the separation of law and politics, stating that populists reject the restriction of political power by legal norms, and they reject the politically neutral conception of law in liberal democracy because it undermines the representation of the national interest; and (2) antielitism, the juxtaposition of the virtuous people and the corrupt elite, and reference to a united people (nation, community) as opposed to a privileged cosmopolitan elite (with international organizations or EU institutions, NGOs included) that protects the rights of LGBTQ communities or immigrants, alternative churches or other minorities that do not represent the majority interest. $^{32}$ Anti-institutionalism, anti-pluralism, and anti-liberalism are the next components that Szente identifies in the literature, ${ }^{33}$ together with the logic that public interest and the general will of the people should take precedence over individual and particular interests.

Among the positive criteria of populist constitutionalism, Szente identifies popular sovereignty first. The populist interpretation of constituent power puts the rule of the people above the rule of law; a 'collective subject' moulded by tradition, common suffering and destiny receives greater competence in direct decision making. Populist constitutionalism can be

\footnotetext{
${ }^{28} \operatorname{Arter}(2011) 490$.

${ }^{29}$ Tushnet and Bugaric (2020).

${ }^{30}$ Batt (1995) 651-762.

${ }^{31}$ Blokker (2017).

${ }^{32}$ See Szente (2021) 3-28.

${ }^{33}$ Szente (2021) 3-28.
} 
characterized by the absolutization of the majority principle, as long as the populist parties have won the election. This majoritarian conception of democracy regards electoral empowerment as an expression of the will of the people and, on that basis, rejects the constitutional restriction of power. ${ }^{34}$ The instrumentalization of the law means, in regimes like Hungary, that the constitution can provide an effective toolbox for preserving power and breaking down checks and balances while the formalities of the rule of law are observed; therefore, these populist regimes are characterized by active constitution-making, as far as this is possible for them. ${ }^{35}$

Francisco Balaguer Callejon explains that there is an unresolvable tension between the populist idea and constitutionalism however, because constitutionalism is based on the idea of pluralism with regard to the nation - the people -, and on the inherent limitation of majority opinion, while populists usually demand that the will of the majority triumphs, and if populists obtain authority over the state they implement this will in the forms of constitutions, constitutional amendments and other legal norms. ${ }^{36}$ An example could be cited from Spain, where secessionists accept the constitutional framework, but when it is against their goals they appeal to a superior will of the 'people' whom they alone represent. It is, however, not the will of the real, plural people, i.e. the people that express themselves through democratic institutions under the rule of law; rather, it is they themselves constituted as a unique 'people', from which they exclude the majority of citizens because they do not coincide with their conception of people. ${ }^{37}$

The reinterpretation of the general ideas of constitutionalism with special regard to popular sovereignty is often mentioned as a per se populist phenomenon. Primarily, the thoughts of U.S. President Abraham Lincoln are used: 'A Government of the people, by the people, and for the people' to reflect on the notion of popular sovereignty as the basis of the democratic order. In relation to this, the phrase 'Give the Government back to the people' is often heard as a criticism of liberal democracy during constitutional transformations.

It is especially typical that national populism highlights the nation as a cultural unity with a national history to be proud of. ${ }^{38}$ According to Eatwell and Goodwin, national populism is a movement that in the early years of the $21^{\text {st }}$ century is increasingly challenging mainstream politics in the West. National populism prioritizes the culture and tradition that belong to the nation, the promise to give voice to a united people. Hungary is classified as a national populist example in this volume. Kaltwasser and Mudde also explain that this form of populism emphasizes that the ultimate source of the people is a collective body, i.e. the nation. The 'common people' is a central notion which refers explicitly or implicitly to a class concept, 'that combines socioeconomic status with specific constitutional traditions and popular values'. When populists speak about the people it is often to critique the dominant state, the institutions, procedures, and the ruling culture. ${ }^{39}$ In opposition to liberal democracy where 'the people' is a word for the integrative and inclusive political community (political nation), in the populist dictionary the people as the source of political power is rather an exclusive and well defined community often

\footnotetext{
${ }^{34}$ Szente (2021) 3-28.

${ }^{35}$ Szente (2021) 3-28.

${ }^{36}$ Balaguer Callejón (2021). Balaguer Callejón (2020).

${ }^{37}$ Balaguer Callejón (2021).

${ }^{38}$ Eatwell and Goodwin (2018) 32.

${ }^{39}$ Mudde and Kaltwasser (2017) 10-11.
} 
based on common cultural, historical religious grounds. Traditions, especially constitutional traditions might be important elements of this new theocratization of the people, the cultural nation.

Cathrine Colliot-Thelene compares how left wing and right wing populisms construct the people and concludes that it is impossible to define the question of the redefinition of the people by populists, because the reference to the people as the source of political power is very different in the different theories. ${ }^{40}$ Manuel Anselmi, however, in his introduction to populism offers a proposition that we should still study the transformation of the notion of the people, in order to understand the operation of a populist regime like Hungary, because this is one key element of constitutional populism. ${ }^{41}$

The notion of the people in the wide palette of understanding is a common element; therefore, I have chosen to examine this in more detail in Hungary, with special regard to the efforts to create a united nation by constituent power and legislative means. Within this effort I have identified the reference to the constitutional traditions that appears to be a common value in the legal texts that serve a basis for the construction of the people and its constitution. Thus far this would be neither unique nor specific in a discussion on populist constitutional changes around the world, but one thing related to this makes the Hungarian case specific in a global context. The reference to constitutional traditions in the constitutional text is not only an ornament in the preamble, not only an anthemic statement, nor only a political statement, but according to the intentions of the constitution making power ${ }^{42}$ - a separate normative order that is fused with the charter constitution, i.e. with the Fundamental Law. Constitutional traditions must be respected when interpreting the constitutional text and other legal texts, and thus, in order to oppose the classic liberal written constitution a hybrid constitution is created, where the past binds the present and the future. The well known dilemma of intergenerational justice ${ }^{43}$ in liberal constitutional democracy has become nuanced by this concept, in which the present binds the future by the past. This is a spectacular contribution to the discussion on time, ${ }^{44}$ law and change, because the Hungarian populist power created a hybrid constitution where the achievements of the historical constitution bind the interpretation of the constitutional court and ordinary courts and legislation and where this construction is integrated into the notion of the constitutional identity which aims to define the unamendable core of the constitution. All this is done in order to identify the uniform nation - the people - with a common constitutional heritage which is binding for the past, present and the future, and which creates the constitution.

\subsection{Populist constitutionalism in Hungary}

Hungary is a country where the government parties enjoy huge popular support, and a constitution-making majority in Parliament. ${ }^{45}$ In the general elections of 2010 , the former

\footnotetext{
${ }^{40}$ Fitzi and Mackert (2018) 23-25.

${ }^{41}$ Anselmi (2018) 87-91.

${ }^{42}$ See the interviews in Ablonczy (2011); Molnár, Németh and Tóth (2013); Vízkelety (2017).

${ }^{43}$ Albert (2017) 18-31.

${ }^{44}$ Ranchordas and Roznai (2020).

${ }^{45}$ This part is based on a previous analysis published as Gárdos-Orosz (2021).
} 
rightist opposition party, Fidesz, and its partner Christian Democratic Party won a landslide victory, and the new government acquired a two-thirds majority under the new favourable electoral rules. In spring of 2011, the Parliament, in the absence of the two democratic opposition parties (which, protesting against the 'destruction of the rule of law', boycotted the whole constitution-making process), approved a new Fundamental Law of Hungary.

The new Fundamental Law, which entered into force on 1 January 2012, introduced certain explicit principles and methods of constitutional interpretation. The original standards of constitutional review were established by the Constitutional Court in the 1990s. The most important interpretive tool was the so-called 'necessity-proportionality test', by which the Court constantly reviewed the constitutionality of rights-limitations, based more or less on the pattern of the jurisdiction of the German Bundesverfassungsgericht. This approach was codified by the Fundamental Law in Art. 1. ${ }^{46}$ Another major general rule on constitutional interpretation was, however, introduced in Art. R para (3) of the Fundamental Law. According to Article R para (3), the provisions of the Fundamental Law must be interpreted (a) 'in accordance with their purposes', (b) 'with the Avowal of National Faith', and (c) 'with the achievements of our historical constitution'. Section (4) of the same Article states that 'the protection of the constitutional identity and the Christian culture of Hungary shall be an obligation of every organ of the State'. According to Art. N) para (1) 'In the course of performing their duties, the Constitutional Court, courts, local governments and other state organs shall be bound to respect the principle that Hungary shall enforce the principle of balanced, transparent and sustainable budget management. ${ }^{37}$

The composition of the Constitutional Court was completely changed, as well. Just a few months after its formation in 2010, the new coalition government, using its two-thirds majority transformed the process of nominating the judges of the Constitutional Court. Since then, the membership of the parliamentary committee responsible for the nomination is no longer based on parity, but has reflected the party-strength in the Parliament. Besides this, Art. 24 of the Fundamental Law introduced a new design, with 15 judges instead of the former 11 . The new constitution empowered Parliament to elect the head of the Court (previously, he or she was elected by the justices themselves).

Both the constitution-making process, and the following amending and legislative activity led not only to fierce debates in the country, but caused a stir on the international level as well. ${ }^{48}$ The reason for this attention and the heavy criticism was that the measures of the two consecutive Orbán Governments after 2010 systematically dismantled the principles of the separation of powers and the rule of law. ${ }^{49}$ These developments and events aroused much

\footnotetext{
${ }^{46}$ The rules relating to fundamental rights and obligations shall be laid down in Acts. A fundamental right may only be restricted in order to allow the exercise of another fundamental right or to protect a constitutional value, to the extent that is absolutely necessary, proportionately to the objective pursued, and respecting the essential content of such fundamental right.' Art. I. para (3) of the Fundamental Law.

${ }^{47}$ Drinóczi, Chronowski and Kocsis (2012) 41-64.

${ }^{48}$ Halmai (2019a).

${ }^{49}$ For a more detailed description of this process, see Kovács and Tóth (2011) 183-203; Pogány (2013) 341-67; Bánkuti, Halmai and Scheppele (2012a) 138-46; Bánkuti, Halmai and Scheppele (2012b) 237-68.

On the international level, the European Parliament and the Venice Commission of the Council of Europe have adopted a number of resolutions and opinions criticizing the backsliding on the rule of law in Hungary. See in details Szente (2017).
} 
criticism in international fora, and induced the EU institutions to establish a mechanism for controlling the state of the rule of law, democracy and fundamental rights in the member states.

The prime minister Viktor Orbán, in a speech in July 2014 openly expressed his views about the policy objectives of the government. While praising Singapore, China, India, Turkey, and Russia as 'making [their] nations successful', and as the new 'stars of international analyses', he said that 'the new state that we are building is an illiberal state, a nonliberal state. ${ }^{50}$

Since the Constitutional Court had been from its very beginnings a powerful counterbalance of the executive power, it is not surprising that the body was involved in constitutional changes. By 2016, all judges of the Constitutional Court were elected for 12 years instead of the former 9 year term and all of them are approved, if not appointed, by the ruling majority. ${ }^{51}$

The Fourth Amendment to the Fundamental Law in March 2013, with the apparent purpose of forcing the body to change its interpretive practice, repealed all the rulings of the Constitutional Court made prior to the entry into force of the Fundamental Law (1st January 2012). ${ }^{52}$ The same amendment which created a hostile environment, openly overruled many former Constitutional Court decisions that had declared important legislative acts of the government majority in Parliament unconstitutional, by inscribing the controversial provisions into the text of the Fundamental Law in order to eliminate any further judicial review. ${ }^{53}$

If we analyse the reasons for the changes of the constitutional environment and especially of the practice of the Constitutional Court since 2010, we can conclude that the world financial crisis, the terrorist danger, the flow of migrants or any other new challenges do not give plausible explanations for the fundamental changes that occurred. Most changes in constitutional jurisprudence have been brought about by the unquestionable semi-authoritarian tendencies building up a so-called 'illiberal democracy', or populist constitutionalism rejecting institutional counterbalances against the executive power and building on its own a state which is based on the united nation.

Of course, even a 'new authoritarianism' might be considered as a special response to the modern challenges of our world. However, if one considers this a realistic option, real answers should be given to emerging problems. Our related question is whether the new Hungarian government's goal to connect a chosen narrative of the past, the present and the future in the normative framework of the constitution appears to be a plausible (legally suitable) solution, or is only a surprising but apparently impossible promise of a quick fix. The attempt is clear - to create a nation according to the theories discussed above. The Hungarian Government majority would like to create a Hungarian nation that supports its constitutional policy and votes for them. This Hungarian nation is composed of Hungarians who have common constitutional traditions, meaning common values that they share and teach.

\footnotetext{
${ }^{50}$ The whole speech can be found at http://hungarianspectrum.wordpress.com/2014/07/31/viktor-orbans-speech-at-thexxv-balvanyos-free-summer-university-and-youth-camp-july-26-2014-baile-tusnad-tusnadfurdo/.

${ }^{51}$ Szente (2016b) 123-49.

${ }^{52}$ Sonnevend, Jakab and Csink (2015) 68.; Uitz (2016) 396.

${ }^{53}$ Sólyom (2015) 22.
} 


\section{THE ‘CONSTITUTIONAL TRADITION’ IN HUNGARY}

The preamble of the new Hungarian Fundamental Law of 2011 declares that '[w]e honour the achievements of our historical constitution and we honour the Holy Crown, which embodies the constitutional continuity of Hungary's statehood and the unity of the nation. We do not recognise the suspension of our historical constitution due to foreign occupations.'

The first chapter of the constitution ('Foundations'), in its Art. I, Para. (1), designating the state symbols, says that in the coat of arms, '[t]he Holy Crown shall rest on top of the shield'.

Although the Holy Crown was already recognized by law as a state symbol in $2010,{ }^{54}$ it only gained real constitutional importance as a principle of constitutional interpretation with the Fundamental Law. Nevertheless, it is still not clear yet, what the significance of the historical constitution and its inherent element, the doctrine of the Holy Crown, is in building the nation's constitutional identity, and what normative consequences they have in constitutional law and interpretation. Almost ten years after the adoption of the Fundamental Law, the achievements of the historical constitution since 2017 form part of the constitutional identity, which is a construction designed to enforce the core of the constitution so that it becomes more stable against change and external intrusion.

Hungary is said to have a 1,000 year old constitutionality, starting from the foundation of the state by Stephen I of Hungary. Hungary's 1,000 years of constitutionality, however, is different from the 1000-year constitutionalism of England. ${ }^{55}$ Before the adoption of the first written constitution of Hungary in 1949, the so-called historical constitution was in effect; however, Hungary, in her long history, was occupied by foreign powers many times, which interrupted constitutional continuity. ${ }^{56}$ The text of the new fundamental law claims that the legal continuity of the historical constitution was broken only by the Nazi occupation in 1944, but the opponents of the revival of the historical constitution and the claim for its legal continuity argue that the continuity of the historical constitution cannot established by a contemporary constitutional charter, therefore the suggestion of the hybrid concept is arbitrary and unviable. ${ }^{57}$

Looking back on Hungarian history, a reference to the elements of the constitutional tradition was usually an ornament of the explanation, used to back up certain institutional or procedural changes as an additional argument, but constitutional traditions usually did not affect any restraint on the political process. ${ }^{58}$ The reference to the constitutional traditions were part of the historical interpretation, which was a conventional way of interpretation in search of additional legal arguments to back up the ratio decidendi of the decision. The constitutional tradition itself was not a legal term in Hungarian law, but was rather present in the political and constitutional discourse in relation to EU law and EU constitutionalism.

The word, tradition is mentioned only twice in the Fundamental Law, but never in the context of constitutional tradition. In Article U) of the Fundamental Law the text condemns the

\footnotetext{
${ }^{54}$ See the Act No. LXXXIII of 1995 on the national symbols of the Republic of Hungary, and the Act No. I of 2000 on the memory of the state foundation by St. Stephen and on the Holy Crown.

${ }^{55}$ Szente (2016a) 23-32.

${ }^{56}$ Szente (2013).

${ }^{57}$ Schweitzer (2017) 143-52.

${ }^{58}$ Vörös (2016) 44-57.
} 
former communist political order: 'The state structure based on the rule of law, established in accordance with the will of the nation through the first free elections held in 1990, and the previous communist dictatorship are incompatible'. The Hungarian Socialist Workers' Party and its legal predecessors and the other political organisations established to serve them in the spirit of communist ideology were criminal organisations, and their leaders shall have responsibility without statute of limitations for, among many others, f) systematically devastating the traditional values of European civilisation.' As I will explain, the traditional values in this context are not the values of liberal constitutionalism, but rather general claims of humanity. The word tradition appears again in another provision as religious tradition in the National Avowal (Preamble) of the text: 'We recognise the role of Christianity in preserving nationhood. We value the various religious traditions of our country'. No other mention is present in the text of the Fundamental Law. The word tradition is used rather generally in legal scholarship. Tradition, legal tradition and constitutional tradition are terms which just as vague as culture, legal culture or constitutional culture. Articles and books use this notion as a general concept, without ever defining its elements. The definition is missing in most cases; the reference to constitutional traditions or constitutional culture is a reference to a positive value that the Hungarian state and nation is assumed to have. Upholding this belief has been very important in the rebuilding of proper statehood after certain historical periods.

According to the Hungarian language dictionary, tradition is 'the habit, morality, taste, or conception that has survived in a written or an unwritten form since ancient times and that is passed on from generation to generation and remains actively applied. ${ }^{59}$ In order to legitimize different political regimes in Hungary, the reference to the legal continuity and the formal or substantive legal continuity of the historical constitution has often played a significant role. Constitutional development, understood as the enforcement of the rule or law, the protection of fundamental rights by law or the separation of powers, was often the result of an external influence on the state, as Hungary was often dependent on, or cooperated with, other states in questions of statehood. The constitutional standards, if not imposed, were often dependent on alliances, external interests, cohabitation and coalitions. In the case of Central European statehoods, it seems to be almost impossible to refer to individual constitutional traditions, making it almost impossible to identify 'typically Hungarian' traditions.

The new Fundamental Law of Hungary chose to refer to the historical constitution, however, as a constitutional tradition that amounts to a source of law which has existed for a long period and continues to do so today. ${ }^{60}$ This approach to certain elements of the constitutional traditions, as part of the contemporary legal system, is very far from the legal positivist approach that was typical of Hungarian law and jurisprudence, not only in the socialist regime which had a longstanding effect on the legal thinking, but later as well. ${ }^{61}$ Therefore when the Constitutional Court first referred to the historical constitution, it referred rather to certain concrete positive norms (pieces of legislation of constitutional value) and classical principles that were in effect at a certain time in history; the constitutional Court rarely referred to conventions or customary

\footnotetext{
${ }^{59}$ 'Tradition' in the Dictionary of the Hungarian Language.

${ }^{60}$ Rixer (2013) 8.; A történeti alkotmányunk is jogforrás! - Horváth Attila a Mandinernek. (2016). Forrás: http:// mandiner.blog.hu/2016/12/15/a_torteneti_alkotmanyunk_is_jogforras_horvath_attila_a_mandinernek

${ }^{61}$ Jakab (2003).
} 
law which would rather have fit with the way the historical constitution was applied in the past. $^{62}$

The introduction of the German type constitutional complaint in the 2011 Fundamental Law is a very interesting development in this regard. (The constitutional complaint was introduced to replace the actio popularis with which, after 1989, anyone could turn to the Constitutional Court by presenting a petition to ask for the abstract review of the constitutionality of a piece of legislation.) The German type constitutional complaint was a substitute, and the two thirds constitution-making majority emphasised that the judiciary should be obliged to interpret all legislative acts according to the provisions of the Fundamental Law. The German type constitutional complaint mechanism seemed to be a good tool to enforce this requirement and therefore the requirement that the constitutional traditions be incorporated in the legal interpretation. The problem is that when the interpretation of the Fundamental Law by the Constitutional Court becomes uncertain, due to the compulsory methods of interpretation prescribed by Article R) of the Fundamental Law (e.g. by taking into consideration and respecting the achievements of the historical constitution), this uncertainty can influence the ordinary judiciary as well. ${ }^{63}$

One problem is that the historical constitution is often described as being substantively incompatible with the present democratic constitutional order, even in cases where the legal continuity is emphasized in the political discourse. ${ }^{64}$ Although, for example, the two-chamber Parliament is a centuries-old tradition in Hungary, and the building itself is constructed accordingly, after the democratic transition of 1989, both constitution making majorities preserved the one chamber Parliament, which was a Communist construction. The constitutional review is also regarded as a very important element of the present state operation; this only dates back to 1990, and was preserved after 2012. Constitutional adjudication is now regarded as a traditional element of the state structure, although such an institution never existed before 1990 in Hungary during the times of the historical constitution.

What is regarded as a constitutional tradition in Hungary according to the Fundamental Law? Uncertainty is a problem that goes hand in hand with the hybrid concept of constitutionalism. The heritage of the 1989 democratic transition is liberal constitutionalism based on the limitation of government, the rule of law, the separation of powers and the protection of human rights, while the achievements of the 1000-year-old historical constitution as it is mentioned by the new Fundamental Law involve the Holy Crown and Christianity and the traditional values of marriage, work and family, etc. The Fundamental Law is explicitly adopted on the basis of the 1989 amendment of the 1949 Constitution (Act XX of 1949 on the Constitution) that codified the democratic transition, ${ }^{65}$ while it departs from that document mostly by defining a different order of values, reaching far back to former national and constitutional traditions as an element of the new order of values. Due to the uncertainty of

\footnotetext{
${ }^{62}$ Szakály (2015) 24-38. And see an almost complete collection of the Constitutional Court references to the historical constitution in Rixer (2018).

${ }^{63}$ Gárdos-Orosz (2019).

${ }^{64}$ Szente (2019) $1-8$.

${ }^{65}$ Point 2 of the Closing Provisions of the Fundamental Law.
} 
these former traditions, however, there is an uncertainty in the present content of constitutionality if it is linked to these former uncertain traditions. ${ }^{66}$

The destruction of liberal democracy after 2010 relied on the political assumption of the constitution making majority that Hungary has strong former constitutional traditions that date back before - indeed far before - the Second World War. ${ }^{67}$ Although the constitutional structure of the state remained quite similar in the Fundamental Law to those of the 1989 Constitution, and the institutions, form of government and rights are almost the same, the constitutional principles and values became different after the nine amendments to the Fundamental Law. We might also say that the chosen constitutional tradition that the Hungarian populist constitutionalism wishes to adopt switched from liberal constitutionalism to national traditionalism within the framework of constitutional democracy. This latter is undoubtedly linked to European constitutional values, but these traditions are not necessarily the exact same as today are represented by the European Council or the European Union.

I will explain in the following that in some cases the so-called constitutional tradition is a contemporary normative creation of the new political elite designed to strengthen the legitimacy of the current government, rather than legal rules and principles which could be or should be applicable straightforwardly in a contemporary legal order based on a written constitution. This is, therefore, not a rule of law legitimacy in a strict sense, meaning that it is not developed by the autonomous legal subsystem itself; in other words, it is not the successful survival of those constitutional norms which are alive and have been enforced over political regimes, generations and even centuries. The contemporary state institutions are empowered by the Fundamental Law to define the content of past constitutional history.

\subsection{The achievement of the historical constitution as a means to define the constitutional traditions after 2012}

In the text of the Fundamental Law, the constitutional traditions, namely the historical constitution, were mentioned as a ground for Hungarian statehood, in addition to the 1989 democratic transition. Some scholars trace the roots of the historical constitution to the state's foundation in 1,000, or earlier, before the conquest in the late 9th century (which was a dominant view among Hungarian legal historians before WWII). ${ }^{68}$

This provision in the Fundamental Law was first regarded by experts as an ideological element in the constitution with little or no legal normative value, but after a while the Constitutional Court tried to define the meaning of the following provisions in the Fundamental Law: In the National Avowal: 'We honour the achievements of our historic constitution and we honour the Holy Crown, which embodies the constitutional continuity of Hungary's statehood and the unity of the nation. We do not recognise the suspension of our historic constitution due to foreign occupations.' Article R (3): 'The provisions of the Fundamental Law shall be

\footnotetext{
${ }^{66}$ As the legal historian Ferenc Eckhart wrote, many articles of the Golden Bull were already invalid a hundred years after its adoption. Eckhart (1932) 316. The most famous article 31 of the Bull, which contained the ius resistendi of the noblemen, was abolished in 1,687.

${ }^{67}$ This idea was implemented into the text of the Fundamental Law. Varga (2016) 83-89.

${ }^{68}$ Zétényi (2010).
} 
interpreted in accordance with their purposes, the National Avowal contained therein and the achievements of our historic constitution.'

To give a normative content to these sentences in the Fundamental Law was a dubious constitutional exercise, since for constitutionalists socialised after 1990 it was completely foreign to merge the - at its roots medieval - concept of the historical constitution with the most recent written constitution in Europe, the adoption of which is based on the 1989 democratic Constitution of the transition. As far as it is interpreted simply as a prescription to use historical interpretation as one of the methods of interpretation (which is used by the Hungarian Constitutional Court anyway), these provisions do not amount to a great challenge to constitutional adjudication. ${ }^{69}$ On the other hand, if it means something more than this, it might be a new concept of hybrid constitutionalism, of which the contours are not yet clear. ${ }^{70}$ The reference found in Article R) to the achievements of the historical constitution could equally be understood as a test. ${ }^{71}$ As I emphasized above, it is up to the contemporary state institutions to decide for one or the other interpretation. The dilemma is still not fully settled in 2020 .

The Constitutional Court's web page lists 79 decisions between 2012 and mid-2020 that mention the historical constitution's achievements, either as part of Art. R) or alone. The 76 mentions are related to the merits of decisions made. There were 92 mentions altogether in the majority-, concurring and dissenting opinions, and some of these mentioned the National Avowal. Although referred to as Art R) or to the historical constitution, some did not contain any related argumentation. Only 30 cases used the achievements of the historical constitution as part of the argumentation. According to Gera, 22 principles were found to be the achievement of the historical constitution along with seven concrete rules. ${ }^{72}$

A popular Act is the Act 1946. évi I. of the Constitution, which is an essential piece of our legal history although it never entered into force; ${ }^{73}$ there were also specific mentions of such concrete rules as the provisions of the Act 1911. évi I. tc. According to legal historians, this state treasury rule was not important as an element of the historical constitution in 1911. Examples of the legal principles could be equality, ${ }^{74}$ or the need to preserve forests, ${ }^{75}$ or maternity benefit. ${ }^{76}$

In some cases, the Constitutional Court referred to the historical constitution without explaining the place of this reference in the argumentation. ${ }^{77}$ In other cases, we read a related historical description without any identification of the historical constitution's achievements ${ }^{78}$.

\footnotetext{
${ }^{69}$ Ádám Rixer identifies four approaches in the interpretation of the Fundamental Law. One is the rejecting, one is the learning, one is the applying and one is the cenetring position. Rixer (2018) 107-17.

${ }^{70}$ Schweitzer Gábor explains the absurdity of this hybridity while András Varga Zs. finds it a progressive legal solution to connect the past, the present and the future to strengthen constitutionalism.

${ }^{71}$ Rixer (2018).

${ }^{72}$ Gera (n. a.).

${ }^{73} \mathrm{CC}$ decision 16/2016. (X. 20.).

${ }^{74} \mathrm{CC}$ decision 85 22/2016. (XII. 5.).

${ }^{75} \mathrm{CC}$ decision 14/2020. (VII. 6.).

${ }^{76} \mathrm{CC}$ decision 3023/2016 (XI. 18.).

${ }^{77} \mathrm{CC}$ decision 45/2012. (XII. 29.); CC decision 5/2013. (II. 21.).

${ }^{78} \mathrm{CC}$ decision 4/2013. (II. 21.); CC decision 6/2013. (III. 1.).
} 
Gera proves that there were only 5 cases in which the Constitutional Court conducted a thorough historical analysis before recognizing the achievement. ${ }^{79}$

In most cases, the historical constitution's identified achievements, such as press freedom, are entirely in line with the content of the Fundamental Law. ${ }^{80}$ This was the general approach in those approximately 3 cases per year in which the achievement of the historical constitution was identified. In a few cases, the range of the achievement was debated. In decision 34/2017. (XII. 11.) $\mathrm{AB}$ hat., the press legislation of 1848 was identified and referred to by the majority opinion. In her dissenting opinion, one judge claimed that if it had respected the real content of this 1848 act, the Constitutional Court must have concluded differently in its opinion.

The Constitutional Court agreed that a decision could not be based solely on the achievements of the historical constitution without finding legal bases in the Fundamental Law. However, the real weight of the reference depends on the specific case. The reference to the historical constitution is always an additional argument. ${ }^{81}$ In this case, however, the question arises of its role and the legitimacy, and the necessity of a reference to it. The dissenting opinion of another judge to point $22 / 2019$. (VII. 26.) focuses on this question by saying that it is hard to recognise the relevance of this provision in domestic constitutional law. This decision considered that our sovereign statehood was an achievement of the historical constitution. The dissenting opinion says that the historical constitution's achievements have their meaning only concerning the EU and the international legal order and the independent place of Hungary and Hungarian constitutionalism. Therefore it should be applied against external legal norms.

Already in 2012, right after the entering into force of the Fundamental Law, the Constitutional Court explained the importance of historical arguments, claiming that without this knowledge 'our present-day public law and our legal culture in general would be rootless'. ${ }^{82}$ In the first years of the application of the Fundamental Law, the Constitutional Court sometimes used merely formal statements, stressing that the body 'took it into account' that certain rights have historical roots embedded in the historical constitution; the freedom of the press, for example, was an achievement of the historical constitution established by the Act XVIII of $1848 .^{83}$ The redundant arguments often appeared in this period, when the old value is the same as the content of the Fundamental Law; in this case the freedom of the press is fully present in the Fundamental Law of 2011 and specified by the media laws adopted in $2010 .^{84}$

On the other hand, in this specific example the achievements of the historical constitution are also contradictory in that, for example, the act of 1848 was a huge step forward in the $19^{\text {th }}$ century towards the freedom of the press, but would be a huge step backwards today in its protection. Szente points out that it is a good example that points to a general problem of the nature of the myths of the constitutional development. Pieces of past legislation, even those with a positive constitutional value with regard to the extension of rights could not be applied literally; they require further contemporary interpretation which is an interdisciplinary project

\footnotetext{
${ }^{79}$ Gera (n. a.)

${ }^{80}$ E.g. CC decision 28/2014. (IX. 29.).

${ }^{81}$ CC decision 25/2018. (XIII. 28.); CC decision 22/2019. (VII. 5.); Gera (n. a.); CC decision 3001/2019. (I. 7.).

${ }^{82} \mathrm{CC}$ decision 33/2012. (VII. 17.).

${ }^{83} \mathrm{CC}$ decision $28 / 2014$. (IX. 29.) and 3002/2018. (I. 10.).

${ }^{84}$ See the Laws CIV and CLXXXV of 2010.
} 
involving history and law, otherwise the legal interpretation is arbitrary. Another good example is that the Constitutional Court referred several times, for example, to the guarantees of judicial independence as an achievement of the historical constitution as if the legal source of these guarantees in Hungarian law were Act IV on the exercise of judicial power of 1869, rather than the current constitution and the Cardinal Act CLXII of 2011 on the legal status and remuneration of judges. Although judicial independence is undoubtedly a stable value of the classical liberal development, it had a different content than is required today. ${ }^{85}$

These references to the legal sources of the past as the sources of contemporary law are also problematic for contentious reasons. The old provisions serve rather as principles than as rules, but this distinction is not clear from the text. In the case of a contentious difference, i.e. a contradiction between the meaning of the old and the new text, doctrinally it could be also possible to reduce the level of protection with reference to the achievement of the historical constitution, which is certainly not a goal in a European legal order.

The interdisciplinary nature of the project causes difficulties in Constitutional Court practice. Decision 16/2016. (X. 20.), for example, refers to the Preamble to Act I of 1946 (Small Constitution) as an achievement of the historical constitution, despite the fact that this law deliberately interrupted the continuity with the ancient historical constitution in all its essential elements, such as the form of government, the issue of sovereignty, or the structure of legislative power. ${ }^{86}$ Carrying this line of interpretation further, László Sólyom, the first president of the Constitutional Court from 1990 to 1999, and later president of the Republic, stated that he would interpret the above mentioned provisions of the Fundamental Law to imply that the constitutional developments from 1989 to 2010, the legislation, constitutional jurisprudence etc. are also part of the historical constitution. ${ }^{87}$ These are interpretations that break with the concept of the historical constitution as understood in Hungarian legal history and try to interpret it freely to preserve the achievements of Act 1 of 1946, the first written constitution that eventually did not enters into force after World War II, and the 1989 liberal democratic constitutionalism.

There are a number of examples in which the CC finds a related rule in previous law and uses it as an achievement of the historical constitution, although not all legal provisions adopted before 1944 were included in the conceptual framework of the historical constitution, only those 'basic' or 'cardinal' laws that concerned the exercise of public power or individual rights and freedoms. ${ }^{88}$

András Varga Zs., a constitutional judge, in one of his concurring opinions referred to the Golden Bull (Aranybulla) of 1222 as an achievement of the historical constitution and therefore a source of the present constitutional provisions in connection with the protection of human rights and limited government. He also referred to the respect for 'public law autonomies' as a legal source of law in connection with so-called Tripartitum of 1517, to the freedom of religion in connection with the laws of Torda in 1568, the requirement of the lawful exercise of public power with reference to the so-called Pragmatica Sanctio of 1723, to parliamentary government

\footnotetext{
${ }^{85}$ Szente (2019) $1-8$.

${ }^{86}$ See the above examples and more, in Szente (2011).

${ }^{87}$ Reference to an interview with László Sólyom in Szakály (2015).

${ }^{88}$ See this opinion and further examples in Hungarian, Szente (2019).
} 
and equality before the law in relation to the revolutionary laws of 1848 , and the principle of the division of power, the recognition of judicial independence and the protection of national minorities linked to the laws of 1867 on the Austro-Hungarian Compromise. ${ }^{89}$

According to Szente, legal historian and constitutionalist, these are undoubtedly important points in legal history. Legal history books thoroughly analyse these elements of the development of law in these periods, but Szente calls our attention to the trivial fact that we have written rules in the positive legal order currently in force in Hungary for the same constitutional issues. $^{90}$ Therefore the reference to these old texts in these cases is redundant, and therefore unnecessary in a legal sense.

Péter Paczolay, who was the head of the Constitutional Court when the new Fundamental Law was born, wrote about the impossibility of the concept of the contemporary historical constitution, a written constitution that takes into account the historical constitution as the source of law. ${ }^{91}$

The living constitutional tradition's approach is rather to find the law in contemporary positive legal sources, - i.e. in domestic, international and European law and jurisprudence and apply the historical interpretation as a method of interpretation in order to understand better the piece of legislation. In many cases the Constitutional Court uses a historical interpretation in essence, although referring to Art. R) of the Fundamental Law and the achievements of the historical constitution. ${ }^{92}$ A methodological problem is that the classical method, or the historical interpretation, is transformed in many cases in the jurisprudence, in order to comply with the Fundamental Law, to a kind of a test to find the relevant achievement of the historical constitution. The procedure is the same in constitutional interpretation but it is referred to differently - instead of the historical interpretation as Jellinek puts it, is a so called 'achievement test'. The goal of both interpretative activities is to find the relevant legal norms of principles in the past and look into them whenever they can help the judge in defining the current content of the constitutional provision in cases of doubt or uncertainty. In legal interpretation, given that the law is a social subsystem, the past, present and the future are fused together, and it is natural to look to the past for advice for the future. But the normative power of this past over the present is in question. In a case in which the past acquires a normative power in present constitutionalism, but it is not clear what the past exactly is, where it depends on the state institutions in a situation when the state institutions are captured by the two thirds political majority representing some or the majority of the people, this leads to a controlled understanding of the past and a controlled understanding of past rules and values. This, in turn, leads to the rule of the people in a position of power, rather than the rule of law - i.e. control by the political power. This results in the problem of uncertainty, a lack of the rule of law and arbitrariness.

As to problem of discrepancy, we must recognise that many of the constitutional traditions we had during the times of the historical constitution are very far from the present-day conception of constitutionalism. Szente points out in his criticism that many important institutions of the Fundamental Law - such as the Republican form of government, the office of the President of the Republic, the neutrality of the state, the institution of the Constitutional

\footnotetext{
${ }^{89}$ See the concurring opinion of Zs. András Varga in the Decision 22/2016. (XII. 5.) of the Constitutional Court.

${ }^{90}$ Szente (2019) 7.

${ }^{91}$ Paczolay (1994) 29-36.

${ }^{92} \operatorname{Gera}($ n. a.).
} 
Court, or the sovereignty transfer within the framework of European Union membership - are fully incompatible with the value order and the system of public powers and fundamental rights under the historical constitution. This is especially true for one central element of the historical constitution, the Holy Crown. ${ }^{93}$

Apart from a very small number of principles and institutions, the content of the historical constitution has been constantly changing over time; ${ }^{94}$ for example, the Golden Bull and the Pragmatica Sanctio have never both been in force in Hungary at the same time, while the revolutionary laws of 1848 radically changed the substantial content of the former feudal law. According to Szente, most components of the historical constitution never existed in the country at the same time. ${ }^{95}$

It hardly needs to be said how difficult it is to determine the precise meaning of the laws of past times ages and their present-day relevance. ${ }^{96}$ In our case, if the relevance cannot be justified with the real necessity of the reference from a legal point of view, ${ }^{97}$ another explanation is needed. This explanation is triggered by the fact that the Fundamental Law should have its own convincing force to create the constitutional statehood itself, which is supported by the people. A possible reason for this normative reference of the historical constitution is that the constitution making and constitution amending two thirds authority wished to carve its legitimacy into the past, to carve it in stone. Populist policy makers desired to create a nation that supports its constitutional politics by this reference to the common and valuable historical past, to continuity, to the achievements of the historical constitution, as the basis of the strong state. The enforcement of the people's, or the nation's, common values created by the constitution making two thirds majority and therefore the strengthening of the community of the people that elects its populist leadership, can be qualified as an element of the national populist constitutionalism in Hungary.

The normative interpretation of the people as a common, united nation was further implemented in the form of the constitutional identity.

Decision 22/2016. (XII. 5.) of the Constitutional Court, according to which Hungary's constitutional identity is based on the historical constitution, says that the Court itself will elaborate on the precise content of constitutional identity in accordance with the historical constitution, from case to case'. In doing so, the Court wishes to examine whether the joint exercise of competences with the EU institutions does not violate Hungary's constitutional identity as it is based on the historical constitution. ${ }^{98}$

\subsection{Constitutional traditions as elements of the constitutional identity - A new phenomenon after 2016}

The legal notion of constitutional identity was born in Hungary in the political context of the migration crisis, when the Hungarian government wished to express its particular standpoint

\footnotetext{
${ }^{93}$ Szente (2013).

${ }^{94}$ Schweitzer (2017).

${ }^{95}$ Szente (2019) 6.

${ }^{96}$ Schweitzer (2014) 17-18.

${ }^{97}$ Drinóczi, Chronowski and Kocsis (2012) 41-64.

${ }^{98}$ Szente and Gárdos-Orosz (2018) 99.
} 
towards the EU and towards the nation. ${ }^{99}$ The elements of the proposed national identity are constitutionalised in the form of the constitutional identity, because - as I described above in the definition of constitutional populism - in Hungary due to the political landscape, the new approach of the populist parties, and especially Fidesz, can very rapidly become part of the constitutional system. ${ }^{100}$

The Hungarian Constitutional Court referred to the section on identity of the Treaty of the European Union, and also referred to many other European constitutional court decisions that formed the concept of national and constitutional identity. The Hungarian national or constitutional identity was expressed in a defence against EU law. Apart from this normative attempt to refer to the national constitutional particularities against EU law, constitutional identity and the constitution itself certainly plays a role in the establishment of the people as the source of legitimacy. ${ }^{101}$

Attempts have been made to spread the new values, partly advertised as national traditions in society: all high school graduates e.g. get an attractive copy of the Fundamental Law. The political idea is well formulated in the concurring opinion of judge András Zs. Varga in Decision 2262016 (XII. 5.) of the Constitutional Court: 'Constitutional self-identity is not a universal legal value, it is a feature of specific States and of their communities, of the nation, that does not apply (the same way) to other nations. In the case of Hungary, national identity is in particular inseparable from constitutional identity. The constitutional governance of the country has been one of the core values the nation has always stuck to, and that has been a living value even at the times when the whole or the majority of the country was occupied by foreign powers.'

In the national Avowal we read the following 'We hold that the protection of our identity rooted in our historic constitution is a fundamental obligation of the State. We do not recognise the suspension of our historic constitution due to foreign occupations.' Article R) (4) states that 'The protection of the constitutional identity and Christian culture of Hungary shall be an obligation of every organ of the State'.

The constitutional identity of Hungary is defined as making reservations primarily in opposition to EU law, which is why it is important to strongly link this with the historical constitution in the argumentation instead of basing it on common European constitutional values. Decision 22/2016 (XII. 5.) of the Constitutional Court was agreed after an unsuccessful amendment to the Fundamental Law to make reservation with reference to Hungarian identity to EU law in the migration crisis in the absence of a two thirds Government majority in Parliament, and after an invalid referendum on the same issue. ${ }^{102}$

Finally, in Decision 22/2016 (XII. 5.), the Constitutional Court decided on the interpretation of the Fundamental Law in favour of the Government's goals. The procedure of interpretation had been requested from the Court by the ombudsman. As explained in the motion, the concrete constitutional issue was related to the European Union's Council Decision (EU) 2015/ 1,601 of 22 September 2015 on migration. ${ }^{103}$

\footnotetext{
${ }^{99}$ Drinóczi (2017).

${ }^{100}$ Rixer (2012).

${ }^{101}$ Sulyok and Deli (2019).

${ }^{102}$ Halmai (2018).

${ }^{103}$ Orbán (2018).
} 
The CC established that the EU provides adequate protection for fundamental rights. The Constitutional Court, however, cannot set aside the protection of fundamental rights either, and it must grant that the joint exercise of competences would not result in the violation of human dignity or the essential content of other fundamental rights the protection is which is part of the constitutional identity.

The Court set two main limitations in the context of the question on the legal acts of the Union that extend beyond the jointly exercised competences. Firstly, the joint exercise of a competence shall not violate Hungary's sovereignty; secondly, it shall not lead to the violation of its constitutional identity. The CC emphasized that the protection of constitutional identity should take the form of a constitutional dialogue based on the principles of equality and collegiality of the partners to the dialogue, implemented with each other's mutual respect. The Constitutional Court established its competence for the examination of whether the joint exercise of powers by way of the institutions of the EU would violate human dignity, another fundamental right, the sovereignty of Hungary or its identity based on the country's historical constitution. ${ }^{104}$

The curiosity of the case is that this is the first time that the CC has ruled explicitly on the relation between EU law and the domestic constitution, claiming that the Fundamental Law has ultimate supremacy in fundamental constitutional questions. Furthermore, the constitutional identity, the inviolable core of the constitution has never previously been defined as such. The country's historical constitution as an element of the non-amendable identity also poses new questions in the Hungarian constitutional order. If the Fundamental Law is amendable up to the point it does not interfere with the historical constitution as a basis, the historical constitution so far undefined in the positive constitutional law might, in effect, have a new, stronger position, at least as a tool of the constitutional interpretation.

The Constitutional Court established in Section III.7.2. of its reasoning that the constitutional self-identity of Hungary is a fundamental value not created by the Fundamental Law - it is merely acknowledged by the Fundamental Law. Consequently, constitutional identity cannot be waived by way of an international treaty - Hungary can only be deprived of its constitutional identity through the final termination of its sovereignty, independent statehood. Therefore, the protection of constitutional identity shall remain the duty of the Constitutional Court as long as Hungary is a sovereign State. ${ }^{, 105}$

Constitutional traditions, whatever they be, according to the above mentioned legal facts are part of the Hungarian constitutional order. Some scholars could easily list the constitutional traditions of Hungary and would trace them back far into history. ${ }^{106}$ Some Hungarian scholars in 2020 would argue that the present constitutional order is 'past dependent', i.e. the elements of the historical constitution are legal facts and sources of law and therefore unchangeable by any new constitution-making political power. Constitutional traditions, as achievements of the historical constitution are the basis of the Hungarian constitutional identity that is inviolable by any domestic or foreign powers. ${ }^{107}$ I tend to be more convinced, however, by those who say - as

\footnotetext{
${ }^{104}$ See our analysis also Bodnár, Gárdos-Orosz and Pozsár-Szentmiklósy (2017) 77-81.

${ }^{105}$ Decision 22/2016 (XII. 5.) Reasoning [67]

${ }^{106}$ Zétényi (2010).

${ }^{107}$ A történeti alkotmányunk is jogforrás! - Horváth Attila a Mandinernek. (Our historical constitution is also a source of law! - Attila Horváth to Mandiner) (2016).
} 
I argued above - that the constitutional traditions, especially in the form of the achievements of the historical constitution can hardly be understood as an additional normative element to the written constitution, to the Fundamental Law. To understand the achievements of the historical constitution as a new source of law that plays a doctrinal role in the interpretation of the Fundamental Law as a test is a troubled concept, because it creates a hybrid constitution, the normative elements of which are unclear and therefore could not be consciously consented to by the constitution making and constitution amending power. On the other hand, these sentences could be understood only as ornaments to the constitutional text (the redundancy argument in the legal sense) and to the ratio decidendi in constitutional court decisions, or, alternatively, it could be argued that the reference to the elements of the historical constitution is not much more than the classical historical method of interpretation. Other legal functions than these are difficult to recognise.

Furthermore, tradition and identity suppose a sort of stability and continuity in the constitutional order. The problem is that this continuity is created as an artificial attempt by the constitution making power in order to strengthen its legitimacy with reference to a united nation, a cultural nation instead of a plural and diverse polity. A tool, a 'quick fix' could be populist constitutionalism, to adopt the new ideas in the form of the constitution and the constitutional law. This is very easy in Hungary, because the Government has a two thirds constitution making majority in the Parliament; furthermore Hungary has a very flexible, easily amendable constitution. The populist's constitutionalism becomes populist constitutionalism in a minute, by constitution making and constitutional amendment; legislation is a quick fix of the political agenda, which identifies itself as illiberal, but which fits into many scholarly descriptions of the national populist regime. Our concern is that the establishment of the achievements of the historical constitution as a source of law in Hungary, the constitutional identity, all the created attributes of the imagined united nation, and the common people-common traditions myth that appear to be political promises made by monolithic public power to society, have been incorporated into the constitutional system without recognisable legal function.

\section{CONCLUSION}

My efforts here have been to analyse the place of constitutional traditions in the constitutional system of a populist state using a legal methodology, i.e. just one more piece to be added to the whole issue of populist constitutionalism, which is basically rather about the process of identity creation, political ideology and communication. With an interdisciplinary approach we could certainly create a more accurate depiction of the entirety of populist constitutionalism, and its rhetorical strategies, because it is not about the legal texts alone but their creation and the 'communication noise' that surrounds this creation. In this paper my goal has been to prove that by introducing such terminology to the legal system without any legal function, the scrutiny of law fades away and the system is transformed into a political vehicle for some sort of identity creation. This is problematic because legal texts must have a recognisable legal meaning and function in a rule of law democracy.

Robert Cover, the American legal theorist, argues that legal texts are surrounded by a rich narrative universe (Nomos), the different stories of identity and meaning. ${ }^{108}$ As Michel Rosenfeld writes in one of his books, the creation of constitutional identity is based on a kind of

${ }^{108}$ Cover (1982). 
selection from these various identities. ${ }^{109}$ This selection clearly appears in the Fundamental Law of Hungary. The question is, however, whether the Nomos is the result of an organic constitutional development with the participation of all state institutions and society, or an imposed and sudden political idea to be enforced in society via the state institutions and law. The creation of the narrative - the identity process - is by nature an autonomous one, if it is to be sustainable and reproduceable in the long run. My paper has proved that in the case of national populist constitutionalism, the understanding of the constitutional traditions in the creation of the constitutional identity and in the interpretation of the other elements of law is not the result of an autonomous constitutional development.

I used the following arguments to provide evidence for the arbitrariness of the introduction of the compulsory nature of the observance as a source of law of the undefined concept of constitutional traditions.

- This summary is based on the suggestions of the anonymous reviewer.

- The problem of 'contradiction': There are many institutions in the present Hungarian constitutional order that are contrary to historical traditions (e.g. the one-chamber Parliament, constitutional adjudication, a republican form of government, the neutrality of the state, the doctrine of the Holy Crown etc.

- The problem of 'redundancy': It is not necessary to refer to the historical constitution if the same regulation exists in the present legal system, in the Fundamental Law. See e.g. the examples concerning the freedom of the press, but it is also true e.g. in relation to the Golden Bull, the Tripartitum, and the Pragmatica Sanctio, the values of which are there anyway in the present legal order.

- The problem of 'incoherence': The 'meaning' of the historical constitution is vague because the historical tradition itself is incoherent. There seem to be many different - often contradictory - approaches to the same issue in Hungarian legal history.

- The problem of 'definition': as I have shown, in some cases it is the rule and in some cases it is the principle that applies. As the content of the historical constitution changed from time to time, it is not possible to list a set of norms that is regarded as the historical constitutional in the past, so the Hungarian Constitutional Court refers to certain old pieces of legislation from history if it sees fit, and in other times it is the principle which is regarded as part of the present legal order by its historical force.

Since there are many problems associated with the idea of the historic constitution 'from a legal point of view', there is no good legal reason for its introduction to the Fundamental Law. Consequently, there must be an 'external', i.e. non legal reason, for this, which is related to constitutional populism: the reference to the constitutional tradition and historic constitution is a 'quick fix' in order to increase the legitimacy of the new constitution and declare a common constitutional heritage of the united nation.

Paul Blokker talked about 'false promises and quick fixes' as one important characteristic of populist regimes. The Hungarian political agenda clearly identifies that the strength of the nation, welfare and peaceful life depends on common values. ${ }^{110}$ These common values are

\footnotetext{
${ }^{109}$ Rosenfeld (2009).

${ }^{110}$ Bartha, Boda and Szikra (2020).
} 
created by the constitution and by the laws. In Hungary the concept of the nation's common constitutional heritage is not only part of the populist rhetoric, but also of the populist constitutional order, because the populist party is in a position to create and alter the constitution and the legal order on its own. This is what we call constitutional populism, the experience of which is very vivid in Hungary. Hungary was and is a litmus paper to study populist constitutionalism.

I have explained in this study that populist constitutionalism operates with the concept of constitutional traditions, which appear in Hungary in the form of the reference to the achievements of the historical constitution. Hungary is special case, because this reference also appears as a compulsory rule of interpretation of the constitutional text and, according to certain interpretations, it leads towards the creation of a hybrid constitution, a written constitution with additional and uncertain elements embedded in the concept of the achievements of the historical constitution.

In the greater context of globalisation and European integration the populist regimes' rediscovery of the concept of sovereignty, constitutional identity and the particular constitutional tradition as part of these, is basically a diplomatic way of saying 'we do within our border whatever we want'. As Pietro Faraguna argues, there are two ways this argument can be used: one is the 'sword' which is used to halt any deeper integration process of the European Union, and the other is the 'shield' where the goal is to head the European discussion in a more appealing direction. ${ }^{111}$ The issue could be further examined in this direction.

\section{LITERATURE}

Ablonczy B., Az alkotmány nyomában. Beszélgetések Szájer Józseffel és Gulyás Gegellyel (In the wake of the Fundmental Law: discussions with József Szájer and Gergely Gulyás) (Elektromédia Kft. 2011).

Albert, R., 'Constitutional Handcuffs' (2017) 1 Intergenerational Justice Review 18-31.

Anselmi, M., Populism: An Introduction (Routledge 2018) 1-130.

Arter, D.: Inside the radical right: The development of anti-immigration parties in Western Europe (Cambridge University Press 2011).

Balaguer Callejón, F., 'Interpretación constitucional y populismo' (2020) 33 Revista de Derecho Constitucional Europeo.

Balaguer Callejon, F., 'Constitutional Interpretation and Populism in Contemporary Spain' in GárdosOrosz, F. and Szente, Z. (eds.), Populist challenge to constitutional interpretation in Europe (Routledge 2021) 217-32.

Bartha, A., Boda, Zs. and Szikra, D., 'When Populist Leaders Govern: Conceptualising Populism in Policy Making' (2020) 3 Politics and Governance 71-81.

Bánkuti, M., Halmai, G. and Scheppele, K. L., 'Disabling the Constitution' (2012a) 323 Journal of Democracy 138-46.

Bánkuti, M., Halmai, G. and Scheppele, K. L., 'From Separation of Powers to a Government without Checks: Hungary's Old and New Constitutions' in Tóth, G. A. (ed.), Constitution for a Disunited Nation. On Hungary's 2011 Fundamental Law (CEU Press 2012b) 237-68.

${ }^{111}$ Faraguna (2019). 
Batt, J., 'American Legal Populism: A Jurisprudential and Historical Narrative, Including Reflections on Critical Legal Studies' (1995) 22 Northern Kentucky Law Review 651-762.

Blokker, P., New Democracies in Crisis? A Comparative Constitutional Study of the Czech Republic, Hungary, Poland, Romania and Slovakia (Routledge 2013).

Blokker, P., 'Populism As a Constitutional Project' (2019) 17 International Journal of Constitutional Law 536-53.

Blokker, P., 'Populist constitutionalism' in Carlos de la Torre (ed.), Routledge Handbook of Global Populism (Routledge 2017) 113-27.

Bodnár, E., Gárdos-Orosz, F. and Pozsár-Szentmiklósy, Z., 'Developments in Hungarian Constitutional Law' in Albert, R., Landau, D., Faraguna, P. and Drugda, S. (eds.), 2016 Global Review of Constitutional Law ICONnect-Clough Center (2017) 77-81.

Bugaric, B., 'The two faces of populism, between authoritarian and democratic populism' (2019) 20 German Law Journal 390-400.

Cover, R. M., 'The Supreme Court 1982 Term. Foreword: Nomos and Narrative' (1982) 97 Harvard Law Review 4-68.

Drinóczi, T., 'A 22/2016 (XII. 5.) AB határozat: mit (nem) tartalmaz, és mi következik belöle. Az identitásvizsgálat és az ultra vires közös hatáskörgyakorlás összehasonlító elemzésben’ (Decision 22/2016 (XII. 5.) of the Constitutional Court: what it [does not] contains and what follows from it. Identity testing and ultra vires shared competence in comparative analysis) (2017) 1 MTA Law Working Papers $<$ http://jog.tk.mta.hu/mtalwp> accessed 10 August 2020.

Drinóczi, T. and Bień-Kacała, A., 'Illiberal Constitutionalism: The Case of Hungary and Poland' (2019) 20 German Law Journal 1140-66.

Drinóczi, T., Chronowski, N. and Kocsis, M., 'What Questions of Interpretation may be Raised by the New Hungarian Constitution?' (2012) 1 Vienna Journal on International Constitutional Law, 4164.

Drinóczi, T., Gárdos-Orosz, F. and Pozsár-Szentmiklósy, Z., 'Formal and informal constitutional amendments in Hungary' (2019) 18 MTA LAW Working Papers <https://jog.tk.mta.hu/mtalwp/formal-andinformal-constitutional-amendment-in-hungary> accessed 10 August 2020.

Eatwell, R. and Goodwin, M., National Populism: The Revolt against Liberal Democracy (Pelican 2018).

Eckhart, F., 'Jog és alkotmánytörténet' (Law and constitutional history) in Hóman, B. (ed.), A magyar történetírás új útjai (Magyar Szemle Társaság 1932) 267-320.

Faraguna, P., 'Constitutional Identity in the EU - A Shield or a Sword?' (2019) 18 German Law Journal $1617-40$.

Fitzi, G., Mackert, J. and Turner, B. S., Populism and the Crisis of Democracy. Volume 1: Concepts and Theory (Routledge 2018).

Gárdos-Orosz, F., 'Constitutional interpretation under the new Fundamental Law of Hungary' in GárdosOrosz, F. and Szente, Z., Populist Challenges to Constitutional Interpretation in Europe and Beyond (Routledge 2021) 143-59.

Gárdos-Orosz, F., 'Challenges to Constitutional Adjudication in Hungary after 2010' in Belov, M. (ed.), The Role of Courts in Contemporary Legal Orders (Eleven Interntional Publishing 2019) 321-40.

Gera, A., 'Történeti alkotmányunk vívmányai az Alaptörvény speciális alkotmányos rendszerében' (The Historical Constitution in the Fundamental Law) (2021) 6 MTA Law Working Papers <https://jog.tk. $\mathrm{hu} / \mathrm{mtalwp} /$ torteneti-alkotmanyunk-vivmanyai-az-alaptorveny-specialis-alkotmanyos-rendszereben> accessed on 10 April 2021.

Ginsburg, T. and Huq, A. Z., How to Save Constitutional Democracy? (University of Chicago Press 2019). 
Graber, M. A., 'Born Populist: The Trump Administration, the Courts and the Constitution of the United States' in Gárdos-Orosz, F. and Szente, Z. (eds), Populist Challenges to Constitutional Interpretation in Europe and Beyond (Routledge 2021) 253-73.

Halmai, G., 'Abuse of Constitutional Identity. The Hungarian Constitutional Court on Interpretation of Article E) (2) of the Fundamental Law' (2018) 43 Review of Central and East European Law 23-42.

Halmai, G., 'Dismantling Constitutional Review in Hungary' (2019a) 18 Rivista de diritti comparati 31-47. Halmai, Gábor. 'Populism, Authoritarianism and Constitutionalism' (2019b) 20 German Law Journal 296313.

Jakab, A., 'A szocializmus dogmatikai hagyatéka' ('The dogmatic legacy of socialism') (2003) 4 Jogelméleti Szemle <http://jesz.ajk.elte.hu/jakab15.html> accessed 10 August 2020.

Kovács, K. and Tóth, G. A., 'Hungary’s Constitutional Transformation' (2011) 167 European Constitutional Law Review 183-203.

Levitsky, S. and Way, L. A., Competitive Authoritarianism. Hybrid Regimes After Cold War (Cambridge University Press 2010) 1-536.

Corrias, L., 'Populism in a Constitutional Key: Constituent Power, Popular Sovereignty and Constitutional Identity' (2016) 12 European Constitutional Law Review 6-26.

Mudde, C. and Kaltwasser, C. R., Populism: A Very Short Introduction (Oxford University Press 2017).

Landau, D., 'Populist Constitutions' (2018) 85 University of Chicago Law Review 521-43.

Müller, J-W., 'Populism and Constitutionalism' in Kaltwasser, C. R. et al. (eds.) The Oxford Handbook of Populism (Oxford University Press 2018) 590-606.

Müller, J.-W.: What is populism? (University of Pensylvania Press 2013) 1-136.

Molnár, B., Németh, M. and Tóth, P. (eds), Mérlegen az Alaptörvény, Interjúkötet hazánk új alkotmányáról, (The Fundamental Law on the balance sheet, interviews about the new constitution of our country) (Hvg-Orac 2013) 1-224.

Orbán, E., 'Quo vadis, “alkotmányos identitás”?' (Quo vadis, “constitutional identity”?') (2018) 3 Közjogi Szemle 1-13.

Pogány, I., 'The Crisis of Democracy in East Central Europe: The "New Constitutionalism"' (2013) 19 European Public Law 341-67.

Paczolay, P., 'A történeti alkotmány és a konzervatív jogi gondolkodás' (The historical constitution and conservative legal thinking) in Tőkéczki, L. (ed), Magyar Konzervatizmus. Hagyomány és Jelenkor (Batthyány Lajos Alapítvány 1994) 29-36.

Ranchordas, S. and Roznai, Y. (ed), Time, Law and Change: an interdisciplinary study. (Hart Publishing 2020) 1-408.

Rixer, Á., A vívmány-teszt (The achievement-test) (Ludovika Egyetemi Kiadó 2018) 1-155.

Rixer, Á., Features of the Hungarian Legal System after 2010 (Patrocinium Kft.2012) 1-174.

Rixer, Á., 'Hungary's Fundamental Law and the concept of the historical constitution' (2013) 4 European Journal of European History of Law 116-23.

Rosenfeld, M., The Identity of the Constitutional Subject: Selfhood, Citizenship and Community (Routledge 2009) 344.

Scheppele, K. L.: 'Autocratic Legalism' (2018) 85 University of Chicago Law Review 545-583.

Sulyok, T. and Deli, G., 'A magyar nemzeti identitás az Alkotmánybíróság gyakorlatában' (The Hungarian national identity in the jurisprudence of the Constitutional Court) (2019) 1 Alkotmánybírósági Szemle.

Schweitzer, G., A magyar királyi köztársaságtól a magyar köztársaságig (From the Hungarian Royal Republic to the Hungarian Republic) (Publikon Kiadó 2017) 153. 
Schweitzer, G., 'Közjogi provizórium, jogfolytonosság, új közjogi irány - Az 1919/1920-1944 közötti magyarországi alkotmányjog-tudomány vázlata, II. rész' (Temporary legal order, Legal continuity, the new direction in public law - Sketch on the Hungarian public legal science between 1919-1944, Part II.) (2014) 2 Közjogi Szemle 8-17.

Sonnevend, P., Jakab, A. and Csink, L., 'The constitution as an instrument of everyday party politics: the basic law of Hungary: The Basic Law of Hungary' in von Bogdandy, A. and Sonnevend, P. (eds), Constitutional Crisis in the European Constitutional Area. Theory, Law and Politics in Hungary and Romania (Nomos Verlagsgesellschaft mbH \& Co. KG 2015) 46-123.

Sólyom, L., 'The Rise and Decline of Constitutional Culture of Hungary' in von Bogdandy, A. and Sonnevend, P. (eds), Constitutional Crises in the European Constitutional Area. Theory, Law and Politics in Hungary and Romania (Nomos Verlagsgesellschaft mbH \& Co. KG 2015) 14-45.

Szakály, Zs., 'A történeti alkotmány és az alkotmányos identitás az Alaptörvény tükrében' (The historical constitution and constitutional identity in the light of the Fundamental Law) (2015) 3 Pro Publico Bono - Magyar Közigazgatás 24-38. <http://uni-nke.hu/uploads/media_items/szakaly-zsuzsaa-tortenetialkotmany-es-az-alkotmanyos-identitas-az-alaptorveny-tukreben.original.pdf $>$ accessed 10 August 2020.

Szente, Z., 'A 2011. évi Alaptörvény és a történeti alkotmány összekapcsolásának mítosza' (The Myth of the connection between the historical constitution and the Hungarian Fundamental Law of 2011) (2019) 12 Közjogi Szemle 1-8.

Szente, Z., 'A historizáló alkotmányozás problémái - a történeti alkotmány és a Szent Korona az új Alaptörvényben' (Problems of the quasi hstorical approach - The Historical constitution and the Holy Crown in the Fundamental Law) (2011) 4 Közjogi Szemle 1-13.

Szente, Z., 'Az angol és a magyar párhuzamos alkotmányfejlődés mítosza' (The myth of the paralel nature of the Hungarian and the English historical constitution) (2016a) 9 Közjogi Szemle 23-32.

Szente, Z., 'Challenging the Basic Values - Problems in the Rule of Law in Hungary and the Failure of the EU to Tackle Them' in Jakab, A. and Dimitry, K. (eds.), The Enforcement of EU Law and Values: Ensuring Member States' Compliance (Oxford University Press 2017) 456-75.

Szente, Z., 'Populism and populist constitutionalism' in Gárdos-Orosz, F. and Szente, Z. (eds.), Populist challenge to constitutional interpretation in Europe (Routledge 2021) 3-28.

Szente, Z., 'The Doctrine of the Holy Crown in the Hungarian Historical Constitution' (2013) 4 Journal of the History of Law 109-15.

Szente, Z.,: 'The Political Orientation of the Members of the Hungarian Constitutional Court between 2010 and 2014' Constitutional Studies (2016b) 1. 123-49.

Szente, Z. and Gárdos-Orosz, F., 'Juridical deference or political loyalty?' in: Szente, Z. and Gárdos-Orosz, F. (eds.), New challenges to constitutional adjudication in Europe (Routledge 2018) 89-110.

Tóth, G. A. 'Constitutional Markers of Authoritarianism' (2019) 11 Hague Journal on the Rule of Law 3761.

Tushnet, M., 'Authoritarian Constitutionalism' (2015) 100 Cornell Law Review 391-462.

Tushnet, M., Taking the Constitution away from the Courts (Princeton University Press 1999) 1-254.

Tushnet, M. and Bugaric, B., 'Populism and Constitutionalism: An Essay on Definitions and Their Implications' Cardozo Law Review (2020).

Uitz, R., 'The Illusion of a Constitution in Europe: the Hungarian Constitutional Court after the Fifth Amendment of the Fundamental Law' in Bell, J. and Paris, M-L. (eds), Rights-Based Constitutional Review. Constitutional Courts in a Changing Landscape (Edward Elgar 2016) 374-405. 
Varga Zs., A., 'Történeti alkotmányunk vívmányai az Alaptörvény kógens rendelkezésében' (The Achievements of our Historical constitution and the Fundamental Law) (2016) 4 Iustum Aequum Salutare 83-89.

Verschraegen, G., 'Hybrid Constitutionalism, Fundamental Rights and the State' (2011) 40 Rechtsfilosofie en Rechtstheorie 216-29.

Vízkelety, M.: 5 éves az Alaptrövény. Válogatás az ünnepi konferenciasorozat beszédeiböl (The Fundamental Law is 5 years old. Selection of speeches from the festive conference series) (Magyar Közlöny 2017) $1-301$.

Vörös, I., 'A történeti alkotmány az alkotmánybíróság gyakorlatában' (The historical constitution in the jurisprudence of the Hungarian Constitutional Court) (2016) 4 Közjogi Szemle 44-57.

Way, L.: Pluralism By Default. Weak Autocrats and the Rise of Competitive Politics (John Hopkins University Press 2015).

Zétényi, Zs. (ed.), A történeti alkotmány - Magyarország ösi alkotmánya (The Historical Constitution - The ancient constitution of Hungary) (Magyarországért Kulturális Egyesület 2010) 1-1164.

Zhang, T., 'The Pragmatic Court: Reinterpreting the Supreme People's Court of China' (2012) 25 Columbia Journal of Asian Law, 1-61.

Viktor Orbán's Speech at the XXV Bálványos Free Summer University and Youth Camp <http:// hungarianspectrum.wordpress.com/2014/07/31/viktor-orbans-speech-at-the-xxv-balvanyos-freesummer-university-and-youth-camp-july-26-2014-baile-tusnad-tusnadfurdo/> accessed 10 August 2020.

'hagyomány' ('tradition'), Dictionary of the Hungarian Language $\leq$ https://www.arcanum.hu/hu/onlinekiadvanyok/Lexikonok-a-magyar-nyelv-ertelmezo-szotara-1BE8B/h-2E554/hagyomany-2E83E/? list=eyJmaWx0ZXJzIjogeyJNVSI6IFsiTkZPX0xFWF9MZXhpa29ub2tfMUJFOEIiXX0sICJxdWV yeSI6ICJoYWd5b21cdTAwZTFueSJ9> accessed 10 August 2020.

A történeti alkotmányunk is jogforrás! - Horváth Attila a Mandinernek. (Our historical constitution is also a source of law! - Attila Horváth to Mandiner) <https://jog.mandiner.hu/cikk/20161214_a_torteneti_ alkotmanyunk_is_jogforras_horvath_attila_a_mandinernek> accessed 10 August 2020.

\section{LEGAL MATERIAL}

Art. I. para (3) of the Fundamental Law

Act No. LXXXIII of 1995 on the national symbols of the Republic of Hungary

Act No. I of 2000 on the memory of the state foundation by St. Stephen and on the Holy Crown

Point 2 of the Closing Provisions of the Fundamental Law

CC decision 16/2016. (X. 20.)

CC decision 85 22/2016. (XII. 5.)

CC decision 14/2020. (VII. 6.)

CC decision 3023/2016 (XI. 18.)

CC decision 45/2012. (XII. 29.)

CC decision 5/2013. (II. 21.)

CC decision 4/2013. (II. 21.) 
CC decision 6/2013. (III. 1.)

CC decision 28/2014. (IX. 29.)

CC decision 25/2018. (XIII. 28.)

CC decision 22/2019. (VII. 5.)

CC decision 3001/2019. (I. 7.)

CC decision 33/2012. (VII. 17.)

CC decision 28/2014. (IX. 29.)

CC decision 3002/2018. (I. 10.)

Laws CIV and CLXXXV of 2010.

Decision 22/2016 (XII. 5.) Reasoning [67]

Opinion of Zs. András Varga in the Decision 22/2016. (XII. 5.) of the Constitutional Court

Open Access. This is an open-access article distributed under the terms of the Creative Commons Attribution 4.0 International License (https://creativecommons.org/licenses/by/4.0/), which permits unrestricted use, distribution, and reproduction in any medium, provided the original author and source are credited, a link to the CC License is provided, and changes - if any - are indicated. (SID_1) 